\title{
Halka Açık ve Halka Açık Olmayan İşletmelerde Finansal Sürekliliğin Denetimi ve Bursa İlinde Bir Araştırma ${ }^{1}$
}

\author{
Ümit Gücenme Gençoğlu ${ }^{\mathrm{a}} \quad$ Alp Aytaç ${ }^{\mathrm{b}}$
}

\begin{abstract}
Öz: Bağımsız denetim standartlarına göre denetçi, 2014 yılından itibaren işletme faaliyet raporunun denetimini de yapmak zorundadır ve bu kapsamda işletmelerin finansal yeterliliği, borç ödeme gücünün tespiti ve işletme risklerinin tespiti yapılır. Sermaye Piyasası Kanunu'na tabi olduğu için 2005 yılından bu yana bağımsız denetime tabi olan halka açık işletmelerde bu süreç, işletmenin finansal sürekliliği üzerinde olumlu etki yapmaktadır. Sermaye piyasası dışında olan işletmelerde bağımsız denetim süreci yeni olduğundan, bu işletmelerde finansal sürekliliğin korunması için yeterli önlemlerin alınmamış olması mümkündür. Bu varsayım üzerine bu çalışmada, Bursa'da faaliyet gösteren ve bağımsız muhasebe denetimine tabi olan halka açık ve halka açık olmayan işletmelerin finansal süreklilik açısından karşılaştırılması amacıyla, iki grup işletmenin 2014-2015 yıllarına ait ortalama oranlarına ilişkin veriler SPSS 24 programında parametrik olmayan yöntemler arasında yer alan Mann Whitney $U$ testine tabi tutularak elde edilen sonuçlar değerlendirilmiştir. Analiz sonucunda Bursa'da denetime tabi halka açık ve halka açık olmayan işletmeler arasında yalnızca aktif devir hızı oranı, özkaynak devir hızı oranı ve özkaynak karlıı̆̆ oranları arasında anlamlı bir farklılı̆ın olduğu tespit edilmiştir.
\end{abstract}

Anahtar Sözcükler: Finansal Süreklilik, Bağımsız Denetim, Halka Açık İşletmeler, Halka Açık Olmayan İşletmeler

JEL Sınıflandırması: M40, M41

\section{Auditing of Financial Sustainability for Publicly and Non-Publicly Listed Companies and A Research in Bursa}

\begin{abstract}
According to the independent auditing standards, the auditor has to carry out the auditing of the annual report from 2014 and in this regards the financial adequacy of the enterprises, determination of the debt payment power and the operating risks are determined. This process has a positive effect on the financial sustainability of the public sector, which is subject to independent examination since 2005 as it is subject to the Capital Market Law. Since independent auditing process is new for companies outside the capital market, it is possible that adequate measures have not been taken to protect financial continuity in these enterprises. Based on this assumption, in this study, in order to compare financial sustainability of publicly traded and non-publicly traded companies which operate in Bursa and subjected to independent audit has been selected. After this selection, these companies' average ratios of 2014-2015 period was entered to the SPSS 24 statistical program. The evaluation has been made based on Mann Whitney $U$ test which is a non-parametric statistical method. As a result of the analysis, it was determined that there is a significant difference between only the turnover ratios, the turnover rate of return on equity and the return on equity ratio among publicly traded and non-publicly traded companies in Bursa.
\end{abstract}

Keywords: Financial Sustainability, Independent Auditing, Publicly-listed Companies, Non-publicly Listed Companies

JEL Classification: M40, M41

aProf., PhD., Uludağ University, Faculty of Economics and Administrative Sciences, Department of Business Administration, Bursa, Turkiye, umitgucenme@uludag.ed.tr

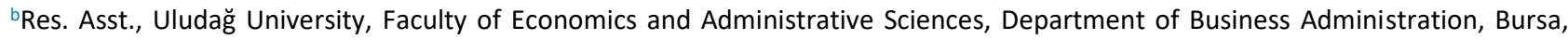
Turkiye, alpaytac@uludag.ed.tr 


\section{Giriş}

Bağımsız Denetim Standartları'na göre denetçi, işletmenin sürekliliği varsayımıyla hazırlanan finansal tablolarını ve yıllık faaliyet raporlarını denetler. Faaliyet raporlarında işletmenin finansal sürdürülebilirliği ile ilgili bilgiler yer almaktadır. Bu kapsamda işletmelerin finansal yeterliliği ile borç ödeme gücünün ve işletme risklerinin tespiti yapılır.

Uluslararası Denetim Standartları (UDS) paralelindeki Türkiye Bağımsız Denetim Standartları (BDS), Türkiye'deki denetim uygulamalarına köklü değişiklikler getirmektedir. Kamuya hesap verme yükümlülüğü bulunan ve sermaye piyasası mevzuatına tabi olan işletmeler 2005 'den bu yana Türkiye Muhasebe/Finansal Raporlama Standartları'na (TMS/TFRS) göre finansal tablolarını hazırlamakta ve bağımsız muhasebe denetimine tabi olmaktadır. Ancak sermaye piyasası dışında olan ve halka açık olmayan işletmelerin bağımsız muhasebe denetimi zorunluluğu 2011 tarihli Türk Ticaret Kanunu (TTK) ile Bakanlar Kurulu Kararı'na bırakılmıştır ve bağımsız denetime tabi olmaya ilişkin kriterler her yıl aşağıya çekilmek suretiyle bağımsız denetim kapsamına alınan işletme sayısı artııımaktadır. Kamu Gözetimi Muhasebe ve Denetim Standartları Kurumu'nun (KGK) 2014 yılında aldığı bir kararla, sermaye piyasası dışında olan ve Bakanlar Kurulu Kararı ile denetime tabi olan işletmelerin TMS/TFRS'lere göre finansal raporlama yapmaları, bu işletmelerin isteğine bırakılmış, KGK tarafindan bir belirleme yapılıncaya kadar Tekdüzen Muhasebe Sistemi'ne göre raporlama yapmaya devam etmeleri belirtilmiştir.

Bağımsız denetim kapsamında faaliyet raporunun ve işletme sürekliliğinin de test edilmesi gerektiğinden, ülkemizde faaliyet gösteren ve halka açık olmayan şirketlerin büyük bir çoğunluğu bağımsız muhasebe denetiminin gereklerine karşı hazır veya donanımlı değildir. Bu çalışmanın amacı, Türkiye Denetim Standartları çerçevesinde bağımsız denetime tabi tutulan ve Bursa'da faaliyet gösteren halka açık işletmelerin finansal sürekliliği ile halka açık olmayan işletmelerin finansal sürekliliğinin karşılaştırılmasıdır.

Makalenin ikinci ve üçüncü kısımlarında halka açık ve halka açık olmayan işletmelerde finansal raporlama çerçevesi ve Bağımsız Denetim zorunluluğu konularına değinilmiştir. Dördüncü kısımda finansal raporlama ve denetim standartlarında işletme sürekliliği kavramı ele alınmış olup beşinci kısım ampirik literatürden oluşmaktadır. Altıncı kısımda ise finansal sürekliliğin karşılaştırılmasına ilişkin Bursa ilinde yapılan araştırmanın amacı, hipotezleri, kapsamı, kullanılan oranlar, analiz yöntemi ve bulguları yer almaktadır. Yedinci bölüm ise elde edilen sonuçlardan oluşmaktadır.

\section{Halka Açık ve Halka Açık Olmayan İşletmelerde Finansal Raporlama Çerçevesi}

Ülkemizde, Sermaye Piyasası Kanunu'na tabi işletmeler Uluslararası Muhasebe/Finansal Raporlama Standartları(UMS/UFRS) ile uyumlu olan Sermaye Piyasası Kurulu'nun "Seri:XI, No: 25 Sermaye Piyasasında Muhasebe Standartları Hakkında Tebliğ"ini 01.01.2005-09.04.2008 tarihleri arasında uygulamışlar, daha sonra bu işletmelerin finansal raporlarını UMS/UFRS veya bunlarla uyumlu olarak Resmi Gazete'de yayımlanan TMS/TFRS'lere göre hazırlamaları zorunluluğu getirilmiştir.

Sermaye Piyasası Kurulu'nun 13.06.2013 tarihli ve 28676 sayılı Resmi Gazete'de yayımlanan "Sermaye Piyasasında Finansal Raporlamaya İlişkin Esaslar Tebliği"ne göre 01.04.2013 tarihinden sonra sona eren ara dönem finansal raporlardan itibaren geçerli olmak üzere TTK ile getirilen yeniliklere uyum sağlanması amacıyla finansal tabloların hazırlanmasında KGK tarafindan yayımlanan TMS/TFRS'lerin esas alınması hüküm altına alınmıştır. Bu düzenlemede "işletme" tanımı, yatırım fonları ile konut finansmanı ve varlık finansmanı fonları dışında kalan tüm ihraççılar ve sermaye piyasası kurumlarını kapsayacak şekilde genişletilmiştir. İ̧̧letme tanımına, borsa dışı halka açık ortaklıklar, ipotek finansmanı kuruluşları, varlık kiralama şirketleri, merkezi takas kuruluşları, merkezi saklama kuruluşları, veri depolama kuruluşları, derecelendirme kuruluşları, değerleme kuruluşları ve bağımsız denetim kuruluşları dahil edilmiştir. Banka ve sigorta şirketlerinde olduğu gibi, sermaye piyasası araçları borsada işlem gören finansal kiralama, faktöring ve finansman şirketlerinin, özel mevzuatlarına göre belirlenmiş şekil ve esaslar çerçevesinde finansal raporlarını düzenlemeleri, bu Tebliğ'de öngörülen finansal rapor düzenleme yükümlülüğünün yerine getirilmesi hükmünde olduğu hususu düzenlenmiştir. Konsolide finansal tablo düzenleme yükümlülüğü bulunan yatırım ortaklıkları, konsolide finansal tablolarının yanında bireysel finansal tablolarını da hazırlamalıdırlar. Bağımsız denetime tabi olacak 
şirketlerin belirlenmesine ilişkin Bakanlar Kurulu Kararı'nda yer alan limitlerin altında kalan borsa dışı halka açık şirketler, iki yıl içerisinde paylarının borsada işlem görmesi için başvuru yapana kadar geçen sürede, bu Tebliğ hükümlerine tabi olmayacaklardır. Bu şirketler isteğe bağlı olarak bu Tebliğ hükümlerine uygun finansal rapor düzenleyebilirler.

Yukarıdaki açıklamalar çerçevesinde, sermaye piyasası mevzuatı kapsamındaki işletmeler TMS/TFRS'lere göre finansal tablo düzenlemeye devam etmektedirler. Ancak sermaye piyasası dışında olup da Bakanlar Kurulu kararıyla bağımsız denetime tabi olan kuruluşların 2014 tarihli bir KGK kararı ile TMS/TFRS'leri uygulaması bu işletmelerin isteğine bırakılmıştır. Standartları uygulamayan işletmelerin KGK tarafindan bir belirleme yapılıncaya kadar yürürlükteki mevzuatı uygulamalarına karar verilmiştir. Bu nedenle bu işletmeler bir düzenleme yapılıncaya kadar Tekdüzen Muhasebe Sistemi'ne göre raporlama yapmaktadırlar. Buna göre TMS/TFRS uygulamayan işletmelerin finansal tablolarında uygulayacakları finansal raporlama çerçevesi Maliye Bakanlığı tarafindan 26.12.1992 tarihli 1 Sıra No.lu Muhasebe Sistemi Uygulama Genel Tebliği (MSUGT) ve ekindeki Tek Düzen Hesap Planı olarak belirlenmiştir. Ancak MSUGT'de değerleme hükümlerinin ihtiyari bırakılmış olması veya öngörülen değerleme hükümlerinin uygulanma şekline ilişkin esasların açıklanmamış olması sebebiyle, Yerel Finansal Raporlama Çerçevesi (YFRÇ) yürürlüğe girinceye kadar geçici çözüm olarak, bağımsız denetime tabi olup TMS/TFRS'leri uygulamayan bu işletmelerin finansal tablolarının hazırlanmasında, MSUGT'lara ek olarak 29.12.2014 tarihli ve 41 sayılı KGK Kararıyla "TMS'leri Uygulamayan Şirketlerin Finansal Tablolarının Hazırlanmasında Uygulanacak ilave Hususlar" yayımlanmıştır. Buna göre, bu grup işletmelerde reeskont işlemleri ihtiyari olup herhangi bir alacak (veya borç) hesap grubunun reeskonta tabi tutulması durumunda buna karşılık gelen borç (veya alacak) hesap grubu da reeskonta tabi tutulur. Varlıklar için değer düşüklüğü hesaplanması ihtiyaridir. Ancak hesap dönemi sonu itibarıyla şirketlerin kıdem tazminat yükümlülükleri tahmin edilir ve bu tahmin nedeniyle cari dönemde ortaya çıkan kıdem tazminatı yükümlülük artşları hesaplanarak giderleştirilir. Kıdem tazminatı yükümlülüğünü ilk defa finansal tablolarına yansıtacak şirketler, bu yükümlülüğün doğduğu hesap döneminden önceki dönemlere ilişkin kıdem tazminatı tutarlarını 10 yılı geçmemek üzere eşit taksitlerle finansal tablolarına yansıtır. Tahmin edilen kıdem tazminat toplam tutarı ile bu tutarın finansal tablolara yansıtılmayan kısmı dipnotlarda açıklanır. Finansal tablolara yansıtllan bu tutarlar gelir tablosuyla ilişkilendirilmeden geçmiş yıllar kârları/zararları altında gösterilir. Buna ilişkin tahmin yöntemi dipnotlarda açıklanır.

TMS/TFRS'lere göre finansal raporlamanın amacı, işletmenin geçmişteki ve şimdiki durumuyla ilgili bilgilere ulaşmak veya gelecekte işletmenin finansal durumunu tahmin edebilmek için, elde edilen bilgilerden hareketle, bilgilerin işletmeyle bağı bulunan kişiler açısından, bilgileri yorumlama ve karar verme gücü sağlamaktır. KGK tarafindan bağımsız denetime tabi olup TMS uygulamayan işletmelerin finansal tablolarında da doğru, ihtiyaca ve gerçeğe uygun sunumu temin etmek ve Avrupa Birliği (AB) mevzuatına tam bir uyum sağlamak üzere Yerel Finansal Raporlama Çerçevesi çalışmalarına başlanmıştır. Yerel Finansal Raporlama Çerçevesi'nin hazırlanmasında; Avrupa Birliği Direktifi, İngiltere'nin UFRS uygulamayan işletmeler açısından yürürlükte olan standardı FRS 102 ve ülkemizde daha önceden uygulanmış muhasebe düzenlemelerinin yanı sıra diğer ülkelerin yerel finansal raporlama çerçevelerinden faydalanılmıştır. 2015 yılında başlatılan çalışmalar neticesinde hazırlanan Yerel Finansal Raporlama Çerçevesi Taslağı, 13.11.2015 tarihinde kamuoyunun görüşüne açılmış ancak henüz bir sonuca ulaşılmamıştır.

\section{Halka Açık ve Halka Açık Olmayan İşletmelerde Bağımsız Denetim Zorunluluğu}

Bağımsız muhasebe denetiminde denetçi, denetim kapsamında; özel ve kamu sektörüne ait kuruluşların; faaliyetlerinin mevzuata uygun olup olmadığı, finansal tablolarının muhasebe ilke ve standartlarına uygunluğu ve kuruluşa tahsis edilen kaynakların etkinlik, verimlilik ve tutumluluk ilkeleri doğrultusunda kullanılıp kullanılmadığını ölçer. Kaliteli bir denetim yapılırsa finansal tablolardaki bilgilerin güvenilir bilgi niteliğini kazanması mümkün olur. Kaliteli bir denetimin yapılması için uyulması gereken kurallar için denetim standartları oluşturulmuştur.

Türkiye'de Sermaye Piyasası Kurulu ve Bankacılık Düzenleme ve Denetleme Kurulu gibi birçok düzenleyici otorite tarafindan ulusal denetim standartları oluşturulurken UDS'ler esas alınmıştır. Sermaye 
Piyasası Kanunu'na tabi işletmelerin bağımsız muhasebe denetimi ile ilgili düzenlemeler, Seri X, No: 22 Sayılı "Sermaye Piyasasında Bağımsız Denetim Standartları Hakkında Tebliğ"de yer almaktadır. KGK tarafindan yayımlanan standart ve düzenlemeler yürürlüğe girinceye kadar uygulanmak üzere, Tebliğ'in ilgili maddeleri KGK düzenlemeleri ile uyumlu bir şekilde değiştirilmiştir. Ayrıca, KGK tarafindan yayımlanan Türkiye Denetim Standartları'nın tamamlanmasını takiben yürürlüğe girmek üzere Sermaye Piyasası Kurulu tarafindan "Sermaye Piyasasında Bağımsız Denetim Yükümlülüğüne illişkin Esaslar Tebliği Taslağı" ile "Sermaye Piyasasında Bağımsız Denetim Faaliyeti Hakkında Tebliğ Taslağı" hazırlanmıştır.

TTK'ya göre denetime tabi olan işletmelerin finansal tabloları, Türkiye Denetim Standartları'na göre denetlenir. Buna göre, şirketin ve şirketler topluluğunun finansal tabloları ile yönetim kurulunun yıllık faaliyet raporunun denetimi; envanterin, muhasebenin ve Türkiye Muhasebe Standartları'nın öngördüğü ölçüde iç denetimin, bu Kanun kapsamında hazırlanan raporların ve yönetim kurulunun yıllık faaliyet raporunun denetimidir. TTK, bağımsız denetimi zorunlu olarak uygulayacak işletmeleri belirleme yetkisini Bakanlar Kurulu'na vermiştir. Bakanlar Kurulu her yıl bağımsız denetime tabi olacak şirketleri belirlemektedir. Avrupa Birliği müktesebatına uyum sağlamak üzere, bağımsız denetim kapsamı zaman içinde kademeli bir şekilde genişletilmektedir. Faaliyet raporlarının bağımsız denetimi 6102 sayılı TTK ile 2014 yılından itibaren kapsamı belirlenen işletmeler için yapılması zorunlu olarak getirilen bir denetim türüdür. Bu kapsamda işletmelerin finansal yeterliliği ve borç ödeme gücünün tespiti, işletme risklerinin tespiti yapılır.

\section{Finansal Raporlama ve Bağımsız Denetim Standartlarında İşletme Sürekliliği}

Genel olarak işletme faaliyetlerinin sonsuza kadar süreceği varsayımı olarak ifade edilen ve genel kabul görmüş temel bir muhasebe kavramı olan işletme sürekliliği, finansal raporlama standartları ve bağımsız denetim standartlarında ayrı ayrı ele alınmaktadır.

\subsection{Finansal Raporlamada İşletme Sürekliliği}

Muhasebe sisteminde işletmelerin finansal raporlamaya intiyaç duymasındaki temel amaç; işletme içinde ya da işletme dışındaki bilgi kullanıcılarına, işletmenin finansal durumu hakkında bilgiler sunmasıdır. Işsletmeler finansal tabloların dışında, işletmenin finansal durumu, finansal performansı, karşılaşılan belirsizlikler ile birlikte işletmenin faaliyette bulunduğu çevredeki değişiklikler ve bunların etkileri, işletmenin temettü politikası, yatırım politikası, fon kaynakları, hedeflenen borç özkaynak oranı ve bilançoda muhasebeleştirilmeyen kaynakları hakkında açıklayıcı bilgiler içeren 'faaliyet raporlarını' sunabilirler. İşletme, finansal tablolarda yansıttlan bilgilerin gerçeğe uygun sunumundan sorumludur. Ayrıca muhasebe politikalarını da içeren bilgiler intiyaca uygun, güvenilir karşılaştırılabilir ve anlaşılabilir olmalıdır (IFRS Foundation 2013:295).

Ülkemizde, tüm işletmeler tarafindan 1994 yılından bu yana uygulanan Tekdüzen Muhasebe Sistemi'ne göre, işletmenin sürekliliği kavramı, işletmelerin faaliyetlerini bir süreye bağı olmaksızın sürdüreceğini ifade eder. Bu kavramın, işletmeler açısından geçerliliğinin bulunmadığı veya ortadan kalktığı durumlarda ise, bu husus mali tabloların dipnotlarında açıklanır. Muhasebe standartlarında finansal raporlamanın amacı, "yönetimin ve ilgili kişilerin ekonomik kararlar almasını sağlamak, varlık ve yükümlüklerin gerçeğe uygun değerleri ile ihtiyaca uygun bilgi sağlamak" olarak ifade edilmektedir. TMS 1Finansal Tabloların Sunuluşu Standardı, ${ }^{2}$ finansal tabloların ne şekilde sunulması gerektiğine dair bilgiler içermektedir. Buna göre, "Yönetimin şirketi tasfiye etme veya ticari faaliyetini sona erdirme niyeti veya mecburiyeti yoksa finansal tablolar süreklilik kavramına göre düzenlenir."

Süreklilik kavramı ekonomik organizasyonun amaçlarını, en azından mevcut taahhütlerini yerine getirmeye yetecek kadar bir süre faaliyette bulunacağını öngörür (Horngren vd., 2012:10). Bu kavram, faaliyetlerin sınırsız bir zaman için organize edilmesini gerektirir (Hendriksen ve Van Breda, 1992:146). Yönetim, değerlendirmelerini yaparken işletme faaliyetlerinin sürekliliğine kuşku düşürecek önemli belirsizlikler taşıyan olaylar veya koşulların farkındaysa, bu belirsizlikleri açıklar. İ̧̧letme, finansal tablolarını süreklilik esasına göre hazırlamamışsa, bunu ve finansal tablolarını hangi temele dayandırdığını, işletmenin süreklilik arz etmeyecek şekilde değerlendirilmesinin nedeni ile birlikte açıklar (TMS 1, madde 25). Eğer 
işletme yönetimince, işletmenin tasfiye edilmesi veya ticari faaliyetlerinin durdurulmasına karar verilmişse, bu durumda hazırlanan tasfiye bilançosu gibi finansal tablolar işletmenin sürekliliği kavramına göre hazırlanmamıştır ve bu durumda işletmenin sürekliliği varsayımının kullanılmadığı, finansal tabloların hazırlanmasında hangi esasın kullanıldığı ve işletmenin sürekliliği varsayımının neden geçerli olmadığı dipnotlarda açıklanır.

\subsection{Bağımsız Denetim Standartlarında İşletme Sürekliliği}

KGK tarafindan UDS'lerin tercümesi olarak Resmi Gazete'de yayımlanan ve BDS kısaltması ile ifade edilen Türkiye Denetim Standartları'na göre denetçi, denetlediği finansal tabloların işletme sürekliliğine göre hazırlanıp hazırlanmadığını test etmeli ve bunu raporunda belirtmelidir. 24.03.2017 tarihindeki Tebliğ ile güncellenen "BDS 570 iş̧letmenin Sürekliliği" Standardı́a göre, işletmenin sürekliliğinin sağlanması ve sürekliliğini olumsuz etkileyen bir durum varsa bunun giderilmesi, öncelikli olarak işletme yönetiminin sorumluluğundadır. Yönetim, işletme faaliyetlerinin sürekliliğine kuşku düşürecek önemli belirsizlikler taşıyan olaylar veya koşullar varsa, bunları açıklar. Denetçinin sorumluluğu, finansal tabloların hazırlanmasında işletmenin sürekliliği varsayımının uygunluğu hakkında yeterli ve uygun denetim kanıtı elde etmek ve işletmenin sürekliliğinin devamına ilişkin önemli bir belirsizliğin var olup olmadığı konusunda bir sonuca varmaktır. Bunun için denetçinin risk değerlendirme prosedürleri, yönetimin yaptğ̆ı değerlendirmelerin incelenmesi, işletmenin sürekliliği üzerinde ciddi şüphe oluşturabilecek olay ve şartlar, uygulanacak ilave denetim prosedürleri gibi konular standartta ayrıntılı olarak ele alınmaktadır. İşletmenin sürekliliği üzerinde ciddi şüphe oluşturabilecek olay ve şartlar varsa, risklerin analizi işletme yönetimine ve sonucunda da denetçiye kalmaktadır. Bu durumda denetçi, BDS 315 uyarınca gerekli olan risk değerlendirme prosedürlerini uygular. Finansal tablolar işletmenin sürekliliği esasına göre hazırlanmış olmasına karşılık, bunun denetçinin yargısına göre uygun olmaması durumunda denetçi olumsuz görüş verir. 2014 yılında KGK tarafindan yayımlanan ve 24.03.2017 tarihindeki Tebliğ ile güncellenen "BDS 700 Finansal Tablolara iliş̧kin Görüş Oluşturma ve Raporlama" Standardı'nda faaliyet raporunun denetimi konusuna açıklık getirilmiş ve Standart ekinde faaliyet raporuna ilişkin denetçi raporu örneğine yer verilmiş, faaliyet raporuna ilişkin olumlu ve şartlı görüş olmak üzere iki tür denetim raporu benimsenmiştir. Şirket yönetim kurulunun yıllık faaliyet raporuna ilişkin sorumluluğu, 6102 sayılı TTK'nın 514 üncü maddesi uyarınca yıllık faaliyet raporunu finansal tablolarla tutarlı olacak ve gerçeği yansıtacak şekilde hazırlamak ve bu nitelikteki bir faaliyet raporunun hazırlanmasını sağlamak için gerekli gördüğü iç kontrollerin yapılmasını sağlamaktır. Bağımsız denetçinin sorumluluğu ise, şirketin faaliyet raporuna yönelik olarak TTK'nın 397. maddesi çerçevesinde yapılan bağımsız denetime dayanarak, bu faaliyet raporunda yer alan finansal bilgilerin şirketin finansal tablolarıyla tutarlı olup olmadığı ve gerçeği yansıttp yansıtmadığı hakkında görüş vermektir. Kanun'un 398. maddesine göre, bağımsız dış denetçi, yönetim kurulunun şirketi tehdit eden veya edebilecek nitelikteki riskleri zamanında teşhis edebilmek ve risk yönetimini gerçekleştirebilmek için 378. maddede öngörülen sistemi ve yetkili komiteyi kurup kurmadığını denetler. Böyle bir sistem varsa bunun yapısı ile komitenin uygulamalarını açıklayan, ayrı bir rapor düzenleyerek, denetim raporuyla birlikte, yönetim kuruluna sunar.

BDS 720 “Bağımsız Denetçinin Denetlenmiş Finansal Tabloları İçeren Dokümanlardaki Diğer Bilgilere ìlişkin Sorumlulukları" başlığını taşımaktadır ve bu standarda göre, denetlenmiş finansal tablolar ile diğer bilgiler arasındaki önemli tutarsızlıklar varsa bu, denetlenmiş finansal tabloların güvenilirliğini zedeleyebileceği için denetçi diğer bilgileri de inceler.

BDS 720-A kapsamında, denetçinin, yönetim kurulunun yıllık faaliyet raporuna ilişkin yasal raporlama sorumluluklarını düzenlemektedir. Buna göre denetçi denetim raporunda, "Diğer mevzuata ilişkin rapor" bölümünde, faaliyet raporunda yer alan bilgilerin finansal tablolar ile tutarlı olup olmadığına ilişkin bir beyanda bulunmalıdır. Denetçinin, faaliyet raporunda yer alan bilgilerin tamlığını doğrulamak veya bu bilgilerin tamlığına ilişkin rapor hazırlamak gibi bir zorunluluğu yoktur. Ancak, mevzuat uyarınca faaliyet raporunda yer alması gereken bir bilginin rapora dâhil edilmediğini fark eden bir denetçi, bu hususu üst yönetimden sorumlu olanlara iletir. Finansal tablolarda değişiklik yapılması gerekiyor ve yönetim ile üst yönetimden sorumlu olanlar söz konusu değişikliği yapmayı reddediyorsa, denetçi, finansal tablolara ilişkin sınırlı olumlu görüş (şartlı görüş) veya olumsuz görüş verebilir. 
Yönetim kurulu faaliyet raporlarında yer verilmesi gereken asgari unsurlar için Gümrük ve Ticaret Bakanlığının 28.08.2012 tarih ve 28395 sayılı Resmi Gazetede yayımlanan "Şirketlerin Yıllık Faaliyet Raporunun Asgari İçeriğinin Belirlenmesi Hakkında Yönetmelik" hükümleri geçerli olup, ilave hususlar belirlenmiştir.

\section{Ampirik Literatür}

Oranlar yoluyla finansal sürekliliğin değerlendirilmesine ve finansal performansın ölçülmesine ilişkin bir çok ampirik çalışma yapılmıştır. Bunlardan bazıları aşağıdaki gibidir.

Altman (1968) tarafindan rasyo analizinin analitik bir teknik olarak kalitesinin değerlendirilmesi için yapılan çalışmada, geleneksel oran analizinin akademik çevrede artık önemli bir analitik teknik olmadığı görüşüne karşı, çok değişkenli bir çerçevede analiz edilirse bir dizi mali oran kullanılarak bir şirketin iflas öngörüsünün istatistiksel olarak önem kazanacağı sonucuna varılmıştır.

Acar (2003) tarafindan tarım işletmelerinde finansal performansın ölçümüne iliş̧in yapılan bir çalışmada, finansal sürekliliğin ölçülebilmesi için ihtiyaç duyulan verilerin kârlılık, likidite, borç ödeme gücü ve verimlilik oranları olduğu belirtilmektedir.

Taylor ve Tower (2011) tarafindan finansal analize yönelik yapılan çalışmada Avustralya'da halka açık 111 firmanın 2002 ve 2006 yılları arasında yıllık raporları incelenerek finansal oranları halka açıklama eğilimleri incelenmiştir. Uluslararası Finansal Raporlama Standartları'nın (UFRS) kabul edilmesinin ardından hazırlanan ilk yıllık raporda mali oranlar ile ilgili açıklamalarda önemli bir artış olduğu ifade edilmiştir.

Savsar ve Karaca (2012) tarafindan yapılan bir araştırmada firma değeri ve finansal oranlar arasındaki ilişki panel veri analizi yöntemi kullanılarak analiz edilmiştir. Araştırma sonucunda finansal oranların firma değerine etkisinin yaklaşık \%20 olduğu, firma değerini artırmak isteyen bir yöneticinin, firma finansal oranları ile bunu sağlayabileceği belirtilmiştir.

Pur ve diğerleri (2015), Çek Cumhuriyeti'nde bulunan şirketlere uyguladıkları anket çalışmasının sonucunda, bir şirketin performansını değerlendirmek için finansal göstergelerin kullanılması gerektiğini, ancak, bu oranların kurumsal sistem içindeki nedensel ilişkileri yansıtmadığını ve genellikle gelecekteki değişiklikleri izleme konusunda yetersiz olduklarını ileri sürmüşlerdir.

Emie ve Hafiza (2016) tarafindan hileli finansal raporlamayı tespit etmek amacıyla oran analizine dayanarak yapılan çalışmada, finansal kaldıraç, varlık yapısı, karlılık ve sermaye dönüşüm oranlarının, hileli finansal raporlamayı tespit etmede önemli tahmin unsurları olduğu ifade edilmektedir. Firmaların yayımlanan denetlenmiş yıllık faaliyet raporlarından elde edilen veriler üzerinde pearson korelasyon analizi ve regresyon sonucunda toplam borç/toplam özkaynak, toplam borç/toplam aktifler, net kâr/gelir, dönen varlıklar/toplam aktifler, alacaklar/gelir, stok/toplam aktifler, işletme sermayesi/toplam aktifler, gelir/toplam aktifler oranlarının hile analizi için önemli göstergeler olduğu ortaya konmuştur.

Deron ve diğerleri (2016) tarafindan yapılan çalışmada, yedi grup finansal oran ve beş grup kurumsal yönetim göstergesi birleştirilerek elde edilen tahmin performansı değerlendirilmiştir. Tayvan Ekonomik Dergisi'nden elde edilen 1999-2009 yıllarına ait veri setine dayanan araştırma sonuçları, ödeme gücü ve karlılığa ilişkin oranların ve kurumsal yönetim göstergelerinin iflas öngörüsündeki en önemli veriler olduğunu göstermektedir.

İçerli ve Akkaya (2006) finansal açıdan başarılı olan işletmelerle başarısız olan işletmeler arasında finansal oranlar yardımıyla farklılıkları tespit etmişlerdir. Çalışmada $Z$ testi yardımıyla ortalamalar arasında anlamlı farklılıklar olup olmadığı tespit edilmiştir. Elde edilen sonuçlar neticesinde aktif devir hızı hariç karlılık, faaliyet ve finansal oranlar açısından herhangi bir farklılık tespit edilememiştir.

Dumanoğlu ve Ergül (2010) İKK'de işlem gören teknoloji şirketlerinin mali performans ölçümünü araştırmışlardır. Çalışmada şirketlerin mali performansları TOPSis yöntemi ile analiz edilerek bir sıralamaya tabi tutulmuş ve firmaların mali analizlerine dayanarak başarılı ya da başarısız oldukları tespit edilmiştir.

Uygurtürk ve Korkmaz (2012) finansal performansın belirlenmesi için, ana metal sanayi işletmeleri üzerinde bir uygulama yapmışlardır. 13 ana metal sanayi işletmesinin 2006-2010 dönemine ait mali tabloları 
kullanılarak finansal performansları TOPSis yöntemi ile analiz edilmiştir. Elde edilen sonuç neticesinde ana metal sanayi sektöründe faaliyette bulunan işletmelerin performans puanlarının analiz döneminde genel olarak değişkenlik gösterdiği vurgulanmıştır.

Delen ve diğerleri (2013) karar ağaçlarını kullanarak mali oranlar ile firma performansını ölçmek için bir araştırma yapmışlardır. İki aşamalı çalışmada, önce keşfedici faktör analizi kullanmışlar, ikinci aşamada ise mali oranların finansal performansa etkisini ölçmek amacıyla dört popüler karar ağacı algoritması olan CHAID, C5.0, QUEST ve C\&RT kullanmışlardır. Çalışma sonucunda CHAID ve C5.0 karar ağacı algoritmalarııın en iyi tahmini ortaya koyduğu gözlemlenmiştir. Aynı zamanda duyarlıık analizi sonucu da vergi öncesi kar özkaynak oranı ve net kar marjının en önemli oranlar olduğu belirtilmiştir.

Ömürbek ve Kınay (2013) Borsa İstanbul'da (BIST) ve Frankfurt Menkul Kıymetler Borsası'nda havayolu taşımacılığı sektöründe faaliyet gösteren birer firmanın 2013 yılına ait finansal durum tablolarını incelemiş, TOPSis yöntemini kullanarak bu iki firmanın finansal performansı arasında nasıl bir farklılık olduğunu ortaya koymaya koymuşlardır. Sonuç olarak BIST'de faaliyet gösteren firmanın daha yüksek finansal performans sergilediği sonucuna ulaşılmıştır.

Tayyar ve diğerleri (2014) BIST'e kayıtlı bilişim ve teknoloji alanında faaliyet gösteren işletmelerin finansal performanslarını Analitik Hiyerarşi Prosesi (AHP) ve Gri Illişkisel Analiz (GiA) yöntemiyle değerlendirmişlerdir. Bu kapsamda araştırmaya dahil edilen işletmelerin 2005-2011 yıllarına ait finansal tablo verilerinden yararlanılarak oran analizi gerçekleştirilmiştir. AHP kullanılarak ağırlığı en fazla olan kriter elde edilmeye çalışımış, GiA ile ise dereceler hesaplanmıştır. Buna göre sektörde en yüksek performansa sahip işletmenin hangisi olduğu ortaya konulmuştur.

Akbulut ve Rençber (2015) BIST imalat sektöründe faaliyet gösteren 32 firmanın 2010-2012 dönemlerine ait finansal performansları üzerine bir araştırma gerçekleştirmişlerdir. Çalışmada 10 adet mali oran ve "pazar değeri/defter değeri" karşılaştırması yapılmıştır. Finansal performansları dikkate alınarak TOPSis yöntemi ile performans skorları elde edilmiştir. Daha sonra, finansal performanslar ile borsa performansları arasındaki ilişki korelasyon yardımıyla incelenmiştir. İşletmelerin finansal performansları ile borsa performansları arasında istatistik olarak anlamlı bir ilişki olmadığı sonucuna ulaşmışlardır.

Selimoğlu ve Orhan (2015) finansal başarısızlığın oran analizi ve diskriminant analizi kullanılarak ölçülmesinde BIST'de işlem gören dokuma, giyim eşyası ve deri işletmeleri üzerine bir çalışma gerçekleştirmişlerdir. Çalışmada finansal başarısızlıkların ölçümlenmesinde yararlanılacak finansal oranların belirlenmesi amaçlanmıştır. Toplam 23 oran içerisinden 7 oranın gruplar arasında anlamlı farklılık gösterdiği tespit edilmiştir. Bu sonuca ulaşmak için tüm gruplar arasında Kolmogorov-Smirnov normallik dağılımı uygulanmıştır. Normallik dağılımı göstermeyenler için ise parametrik olmayan testlerden Man-Whitney $U$ testi uygulanmıştır. Analiz sonuçlarına göre duran varlıklar/özkaynaklar, faiz karşılama, faaliyet kar marjı, net kar marjı, özkaynak karlıı̆̆ı, aktif karlılığı ve Faiz ve vergi öncesi kar/aktif toplam oranlarının finansal açıdan başarılı ve başarısız olan işletmeler arasında anlamlı farklılık gösterdiği bilgisine ulaşılmıştır. Aynı zamanda finansal açıdan başarısız olan işletmelerin, özellikle özkaynaklar ve aktifler ile ilgili oranlarda, finansal açıdan başarısız olmayan işletmelerden ayrıldığı sonucuna ulaşıımıştır.

Bursa'da faaliyet gösteren şirketler üzerinde yapılan çalışmalar dikkate alındığında Lazol (2011) tarafindan Bursa'daki en büyük 250 firmanın borç ödeme gücü, likidite durumu, mali yapı ve karlılıkla ilgili oranları değerlendirilmiş ve işletmelerin genel olarak borçla finansmana ağırlık verdiği ve geçmiş yıllardan gelen trendin sürdüğü sonucuna varılmıştır. Aynı zamanda borç ödeme gücüyle ilgili göstergeler geçmiş yıllarla uyumlu kalmış olmakla birlikte olumlu yönde küçük düzelmeler görüldüğü ve işletmelerin karlılıklarında iyileşmeler gözlemlendiği sonucuna ulaşımıştı. Dış ticaret bakımından da ihracat artş̧ları 2006-2011 yılları arasında dalgalanmalar göstermiştir. Son olarak işletmelerin yarattı̆ı katma değer büyüklüklerinde 2011 yılında bir önceki yıla göre artş̧ meydana geldiği sonucuna ulaşılmıştır.

Bursa'daki en büyük 250 firma üzerinde Bilgin (2011) tarafindan yapılan diğer bir araşttrmada, bu şirketlerin 2011 yılındaki verileri kullanılarak yıl ve sektörel bazda karlılı üzerine değerlendirmeler yapılmıştır. Analiz sonuçlarına göre otomotiv ana ve yan sanayi ile tekstil ve konfeksiyon sektörlerinin Bursa 
ekonomisinde önemli bir ağırlığa sahip ve bu sektörlerin büyük ölçüde ihracata yönelik üretim yapmasının olumlu bir sonuç olduğu bilgisine ulaşılmıştır.

Literatür incelendiğinde finansal performansın tespitinde genellikle mali oranların kullanıldığı ve araştırmaların çoğunlukla halka açık olan işletmeler üzerinde yoğunlaştığı görülmektedir. Halka açık olmayan işletmeler üzerinde yapılan araştırma sayısının daha az olmasının nedeni, bu işletmelerin finansal verilerini paylaşmaya sıcak bakmamaları olarak ifade edilebilir.

\section{Finansal Sürekliliğin Karşılaştırılmasına İlişkin Bursa İlinde Bir Araştırma}

\subsection{Araştırmanın Amacı ve Hipotezler}

Bağımsız Denetim Standartları'na göre, işletmenin finansal sürekliliğinin korunduğuna dair bağımsız denetçinin denetim raporunda görüş bildirmesi gerekir. Denetçi bu konuda görüşe varabilmek için, işletmenin sürekliliğine ilişkin değerlendirmeler yapmalı, işletmenin likiditesi, finansal yapısı ve karlılığına ilişkin analizler neticesinde, finansal süreklilik üzerinde ciddi şüphe oluşturabilecek şartlar varsa, bunu denetim raporunda belirtmeli, işletme yönetimini uyarmalı, gerekiyorsa olumsuz rapor vermelidir. Sermaye Piyasası Kanunu'na tabi olduğu için 2005 yılından bu yana bağımsız denetime tabi olan halka açık işletmelerde bu süreç, işletmenin finansal sürekliliği üzerinde olumlu etki yapmaktadır. Ancak sermaye piyasası dışında olan işletmelerde bağımsız denetim süreci yeni olduğundan, bu işletmelerde finansal sürekliliğin korunması konusunda yeterli önlemlerin alınmamış olması mümkündür. Bu varsayım üzerine, merkezi Bursa'da olan ve bağımsız muhasebe denetimine tabi olan halka açık ve halka açık olmayan işletmelerin finansal süreklilik açısından karşılaştrııması amacıyla yapılan araştırmada, her iki grupta yer alan işletmelerin finansal sürekliliğini gösteren oranların ortalamaları kullanılmıştır. Bu oranlar, şirketlerin borç ödeme güçleri, finansal yapıları, karlılıkları ve varlıklarının etkin kullanımı hakkında bilgi verebilecek nitelikteki oranlar arasından seçilmiştir ve iki grup arasında anlamlı bir fark olup olmadığı test edilmektedir. Bu oranların her biri için ilk hipotez "anlamlı bir fark yoktur" şeklinde, karşıt hipotez ise "anlamlı bir fark vardır " şeklinde kurulmuştur. Buna göre araştırma hipotezleri aşağıdaki gibidir.

$H_{o}$ : Bursa faaliyet gösteren ve bağımsız denetime tabi olan halka açık işletmeler ile halka açık olmayan işletmelerin mali oranları arasında anlamlı bir farklılık yoktur.

$\mathrm{H}_{1}$ : Bursa faaliyet gösteren ve bağımsız denetime tabi olan halka açık işletmeler ile halka açık olmayan işletmelerin mali oranları arasında anlamlı bir farklılık vardır.

\subsection{Araşttrma Kapsamı}

Çalışmanın ana kütlesini, Bursa'da faaliyet gösteren denetime tabi halka açık olan ve halka açık olmayan işletmeler oluşturmaktadır. Bursa'da faaliyet gösteren ve halka açık olan 14 işletme bulunmaktadır ve bu işletmelerin tamamına ait veriler Kamuyu Aydınlatma Platformu'nun internet sayfasından ulaşılmıştır. Bursa'da denetime tabi halka açık olmayan işletmelerin toplam sayısına ulaşmak için, Bursa Ticaret ve Sanayi Odası'nın (BTSO) yayımlamış olduğu ilk 250 büyük firma listesinden 2014 ve 2015 yılları bilanço ve gelir tablosu rakamlarına göre, 2016 yılında bağımsız denetime tabi olma koşullarını sağlayan işletmeler tespit edilmiştir. Buna göre Bursa'da faaliyet gösteren ve halka açık olmayan 102 işletmenin bağımsız denetime tabi olduğu belirlenmiştir. Bunlardan finansal tablolarına ulaşılabilen 21 şirketin 2014 ve 2015 yılına ait yıllık bilanço ve gelir tabloları analiz edilmiştir. Buna göre, Bursa'da faaliyet gösteren halka açık işletmelerin tümünün finansal tablolarına ulaşılabildiği halde, halka açık olmayan işletmelerden finansal tablolarına ulaşılabilen işletme sayısının toplam sayıya oranı \%20,5 olarak gerçekleşmiştir. Çalışma kapsamındaki toplam 35 işletmenin 21'i (\%60) bağımsız denetime tabi halka açık olmayan işletmeler, 14'ü ise (\%40) halka açık işletmelerden oluşmaktadır

Çalışmada kapsama dahil olan işletmelerin 2014 ve 2015 yıllarına ait yıllık bilanço ve gelir tabloları kullanılmıştır. Faaliyet raporlarının bağımsız denetimine ilişkin BDS 700'ün yayımlanma yılı 2014 olduğundan, kullanılan veriler 2014-2015 yılı karşılaştırmalı finansal tabloları ile sınırlandırılmıştır. Kapsama alınan işletmeler 2016 yılında denetime tabi olan işletmelerdir. Halka açık işletmelerin tamamında bağımsız denetim 
uygulanmaktadır. Halka açık olmayan işletmelerin ise 2016 yılında denetime tabi olması için, 19 Mart 2016 tarihli Resmi Gazetede yayınlanan Bakanlar Kurulu Kararı'na göre aktif toplam 40 milyon TL ve üzeri, net satış hasılatı 80 milyon TL üzeri ve çalışan sayısı 200 kişi ve üzeri olması ve bu kriterlerden en az ikisine iki yı üst üste sahip olması gerekmektedir. Bu nedenle, halka açık olmayan işletmelerden çalışma kapsamına alınanlar, 2014 ve 2015 finansal tablolarındaki verilere ve BTSO’nun yayımlamış olduğu ilk 250 büyük firma listesindeki rakamlara göre seçilmiştir.

\subsection{Kullanılan Oranlar}

Çalışmada kullanılan aşağıdaki oranlar veri setini oluşturmaktadır. Bu oranlar şirketlerin borç ödeme güçleri, finansal yapıları, karlılıkları ve varlıklarının etkin kullanımı hakkında bilgi verebilecek nitelikteki oranlar arasından seçilmiştir.

Tablo 1. Kullanılan Oranlar

\begin{tabular}{|c|c|}
\hline Oranlar & Hesaplanışı \\
\hline Cari Oran & Dönen Varlıklar/Kısa Vadeli Yabancı Kaynaklar \\
\hline Asit-Test Oranı & $\begin{array}{c}\text { Dönen Varlıklar-Stoklar } \\
\text { Kısa Vadeli Yabancı Kaynaklar }\end{array}$ \\
\hline Nakit Oranı & $\frac{\text { Dönen Varlıklar-Stoklar- Alacaklar }}{\text { Kısa Vadeli Yabancı Kaynaklar }}$ \\
\hline Kaldıraç Oranı & Toplam Borç / Toplam Aktif \\
\hline Kısa vadeli yabancı kaynakların toplam kaynaklara oranı & Kısa Vadeli Yabancı Kaynaklar / Pasif Toplam \\
\hline Özsermayenin toplam kaynaklara oranı & Özsermaye/ Pasif Toplam \\
\hline Aktif Devir Hızı Oranı & Net Satışlar / Toplam Aktif \\
\hline Özsermaye Devir Hızı Oranı & Net Satışlar / Özsermaye \\
\hline Satış Karlılığı & Net Kar / Net Satışlar \\
\hline Özsermaye Karlı̆ı̆ı & Net Kar / Özsermaye \\
\hline Brüt Karlıık Oranı & Net Kar/ Brüt Kar \\
\hline
\end{tabular}

Likidite oranları (cari oran, asit-test oranı ve nakit oran) işletmenin kısa vadeli borçlarını ödeme gücünü ortaya koymak amacıyla kullanılan oranlardır. Finansal yapı ile ilgili oranlar (Kısa vadeli yabancı kaynak-pasif toplam oranı, öz sermaye-pasif toplam oranı) işletmenin finansmanında yabancı kaynaklardan ne derece yararlanıldığını ortaya koyan oranlardır. Yabancı kaynaklar ile öz kaynaklar arasındaki ilişkiyi gösteren bu oranlar işletmenin finansal yapısının ve kredi verenlerin emniyet payının yeterli olup olmadığı sorularına cevap vermektedir. Faaliyet oranları (aktif devir hızı oranı, öz sermaye devir hızı oranı) aktiflerin işletme faaliyetlerinde kullanılmaları sırasında etkinlik derecesini ölçen oranlardır. Karlılık oranları ise (satış karlılığı oranı, öz sermaye karlılığı oranı ve net kar-brüt kar oranı) faaliyetler sonucunda ulaşılan başarıyı ölçmek için kullanılan oranlardır (Gücenme Gençoğlu, 2014:93-104).

\subsection{Veri Analiz Yöntemi}

Veri analizi için, parametrik olmayan analiz yöntemlerinden Mann Whitney-U analizi kullanılmıştır. Bu yöntem, iki ilişkisiz örneklemden elde edilen puanların birbirinden anlamlı bir şekilde farklılık gösterip göstermediğini, bir başka deyişle, iki ilişkisiz grubun, ilgilenilen değişkenler bakımından evrende benzer dağılımlara sahip olup olmadığını test eder ve az denekli çalışmalarda sıklıkla kullanılır (Büyüköztürk, 2013; 
165). Mann-Whitney-U testi küçük örnekler ve büyük örnekler olmak üzere iki şekilde uygulanabilir, örneklerden birisinin 20 gözlemi aşması halinde veya her iki örneğin de 10 veya daha çok gözleme sahip olması durumunda büyük örnek yaklaşımı izlenir (Kartal, 2014; 198). Sümbüloğlu ve Sümbüloğlu (2005)'e göre her gruptaki denek sayısı 30'dan az ise ya da denek sayısı yeterli olduğu halde veri parametrik test varsayımlarını yerine getiremiyorsa kullanılabilecek en güçlü test Mann-Whitney U Testi'dir. Çalışmamızda kullanılan 35 örneklem sayısı, hem Büyüköztürk'ün (2013) az denekli kriterini, hem Kartal'ın (2014) her iki örneğin de 10 veya daha çok gözleme sahip olması kriterini ve hem de Sümbüloğlu ve Sümbüloğlu'nun (2005) denek sayısı 30'dan az olması kriterlerini sağladığından, veri analiz yöntemi olarak Mann Whitney U yöntemi kullanılmıştr.

\subsection{Bulgular}

Tablo 2'de denetime tabi halka açık olmayan 21 işletmenin ve halka açık olan 14 işletmenin mali oranlarının Mann Whitney-U Testi sonucu ve oran ortalamaları yer almaktadır.

Tablo 2. Mann-Whitney U Analiz Sonuçları ve Oran Ortalamaları

\begin{tabular}{|c|c|c|c|c|}
\hline DEĞişKENLER & FiRMA TiPi & Sayı & $P$ & Ortalamalar \\
\hline Cari Oran & $\begin{array}{c}\text { Halka Açık Değil } \\
\text { Halka Açık }\end{array}$ & $\begin{array}{l}21 \\
14\end{array}$ & 0,516 & $\begin{array}{l}1,93 \\
3,62\end{array}$ \\
\hline Asit Test Oranı & $\begin{array}{c}\text { Halka Açık Değil } \\
\text { Halka Açık }\end{array}$ & $\begin{array}{l}21 \\
14\end{array}$ & 0,516 & $\begin{array}{l}1,42 \\
3,00\end{array}$ \\
\hline Nakit Oranı & $\begin{array}{c}\text { Halka Açık Değil } \\
\text { Halka Açık }\end{array}$ & $\begin{array}{l}21 \\
14\end{array}$ & 0,606 & $\begin{array}{l}0,30 \\
1,90\end{array}$ \\
\hline Kaldıraç Oranı & $\begin{array}{c}\text { Halka Açık Değil } \\
\text { Halka Açık }\end{array}$ & $\begin{array}{l}21 \\
14\end{array}$ & 0,325 & $\begin{array}{l}0,64 \\
0,52\end{array}$ \\
\hline $\begin{array}{l}\text { Kısa vadeli yabancı } \\
\text { kaynakların pasif } \\
\text { toplamına oranı }\end{array}$ & $\begin{array}{c}\text { Halka Açık Değil } \\
\text { Halka Açık }\end{array}$ & $\begin{array}{l}21 \\
14\end{array}$ & 0,325 & $\begin{array}{l}0,41 \\
0,32\end{array}$ \\
\hline $\begin{array}{c}\text { Özkaynakların pasif } \\
\text { toplamına oranı }\end{array}$ & $\begin{array}{c}\text { Halka Açık Değil } \\
\text { Halka Açık }\end{array}$ & $\begin{array}{l}21 \\
14\end{array}$ & 0,434 & $\begin{array}{l}0,38 \\
0,48\end{array}$ \\
\hline Satış Karlııı̆ı oranı & $\begin{array}{c}\text { Halka Açık Değil } \\
\text { Halka Açık }\end{array}$ & $\begin{array}{l}21 \\
14\end{array}$ & 0,495 & $\begin{array}{l}0,03 \\
0,09\end{array}$ \\
\hline Brüt karlılık oranı & $\begin{array}{c}\text { Halka Açık Değil } \\
\text { Halka Açık }\end{array}$ & $\begin{array}{l}21 \\
14\end{array}$ & 0,960 & $\begin{array}{l}0,28 \\
0,26\end{array}$ \\
\hline Aktif devir hızı oranı & $\begin{array}{c}\text { Halka Açık Değil } \\
\text { Halka Açık }\end{array}$ & $\begin{array}{l}21 \\
14\end{array}$ & 0,000 & $\begin{array}{l}2,19 \\
0,68\end{array}$ \\
\hline $\begin{array}{c}\text { Özkaynak devir hızı } \\
\text { oranı }\end{array}$ & $\begin{array}{c}\text { Halka Açık Değil } \\
\text { Halka Açık }\end{array}$ & $\begin{array}{l}21 \\
14\end{array}$ & 0,001 & $\begin{array}{l}7,29 \\
1,90\end{array}$ \\
\hline $\begin{array}{c}\text { Özkaynak karlılığı } \\
\text { oranı }\end{array}$ & $\begin{array}{c}\text { Halka Açık Değil } \\
\text { Halka Açık }\end{array}$ & $\begin{array}{l}21 \\
14\end{array}$ & 0,001 & $\begin{array}{l}-0,02 \\
0,45\end{array}$ \\
\hline
\end{tabular}


Tablo 2'de üzerinde durulması gereken yer $\mathrm{P}$ sütunudur. $\mathrm{P}$ değeri değişkenler arasında istatistiksel farkın var olup olmadığını tespit etmek için kullanılan rakamdır. Çalışmada hipotezlerin kabul ya da red edileceğini gösteren değer olarak 0,05 değeri kullanılmıştır. 0,05 değeri çalışmada bulunan hata payını göstermektedir. Diğer bir ifadeyle, çalışmada \%95 güvenilirlik mevcuttur. $P$ değeri 0,05 'ten büyük ise farksızlığı savunan $\mathrm{H}_{0}$ Hipotezi kabul edilirken bu değerin 0,05 'ten küçük olması durumunda ise farklılığı savunan $\mathrm{H}_{1}$ hipotezi kabul edilir.

Tablo 2'de belirtilen P değeri sonuçlarına göre ortalama oranlar için bulunan değerler doğrultusunda Bursa'da faaliyet gösteren denetime tabi halka açık olan ve halka açık olmayan firmaların 2014-2015 yılındaki cari oran, asit test oranı, nakit oranı, kaldıraç oranı, kısa vadeli yabancı kaynakların pasif toplamına oranı, özkaynakların pasif toplamına oranı, satı̧ karlılı̆ıı oranı ve brüt karlıık oranı ortalamaları için p $>0,05$ olduğu için iki grup arasında anlamlı bir farklılık olduğunu öne süren $\mathrm{H}_{1}$ hipotezi reddedilir ve farksızlığı savunan $\mathrm{H}_{0}$ hipotezi kabul edilir. Öte yandan $p<0,05$ olması nedeniyle Bursa'da denetime tabi halka açık olan ve halka açık olmayan firmaların 2014-2015 yılındaki aktif devir hızı, özkaynak devir hızı ve özkaynak karılı̆̆ı ortalama oranları bakımından anlamlı bir farklılık olmadığını öne süren $\mathrm{H}_{0}$ hipotezi reddedilir ve farklılığı savunan $\mathrm{H}_{1}$ hipotezi kabul edilir.

Çalışmamızdaki araştırma bulgularımıza göre, aktif devir hızı ve özkaynak devir hızı oranı ile özkaynak karlııı̆ı oranlarının ortalamaları, her iki grup için farklılık göstermektedir. Özkaynak devir hızı, 2014-2015 yılları ortalamaları itibariyle, halka açık olmayan işletmelerde 7,29 iken bu oran halka açık olan işletmelerde 1,90 'dır. Net satışlar/özkaynaklar olarak hesaplanan bu oranın yüksek olması özkaynakların verimli kullanıldığı ya da özkaynakların yetersiz olduğu şeklinde yorumlanabilir. Özkaynakların pasif toplamına oranı açısından iki grup işletme arasında anlamlı bir fark olmadığı yönünde sonuç bulunmuş olsa da özkaynakların pasif toplamına oranı, halka açık şirketlerde \%48, halka açık olmayanlarda ise \%38 olarak hesaplanmıştır. Bir başka deyişle, finansal kaldıraç oranı ( borç oranı) halka açık işletmelerde daha düşük, özkaynak oranı ise daha yüksektir. Halka açık olmayan işletmelerde, özkaynakların daha düşük olması, özkaynak devir hızı oranının yüksek olmasının bir nedeni olsa da, bu işletmelerde oranın yüksek olması, bu grup için özkaynakların verimli kullanıldığı ve satışlara dönüştüğü şeklinde yorumlanmalıdır. Ayrıca özkaynakların karlılığı oranı ortalamaları, halka açık olmayan işletmelerde 0.45 iken halka açık olan işletmelerde $-0,02$ olarak tespit edilmiştir. Bu konuda halka açık işletmelerin kar payı dağıtımından kaçınmak için daha fazla kar yönetimi uyguladığı ya da satı̧ maliyetlerinin daha yüksek olduğu şeklinde yorumlanabilir. Neticede bu sonuçların halka açık işletmeler lehine yorumlanması mümkün olmamaktadır.

Aktif devir hızı oranı 2014-2015 yılları ortalamaları itibariyle, halka açık olmayan işletmelerde 2,19 iken halka açık işletmelerde 0,68 olması da aktiflerin halka açık olmayan işletmelerde daha verimli kullanıldığı sonucunu ifade etmektedir.

Tablo 2'den görüldüğü gibi nakit oranı halka açık işletmelerde 1,90 iken, halka açık olmayan işletmelerde 0,30 olması, halka açık işletmelerin nakit ve nakit benzerleri ile kısa vadeli borçlarını ödeme gücünün daha yüksek olduğunu ifade etmektedir. Ancak, diğer veriler ile birlikte değerlendirildiğinde bu, halka açık işletmelerin finansal performanslarının halka açık olmayan işletmelere göre daha yüksek olduğu savını doğrulamak için yeterli olmamaktadır. Bu nedenle varılan genel sonuç, Bursa'da bağımsız denetime tabi olan halka açık işletmelerin ve halka açık olmayan işletmelerin 2014-2015 yıllarına ait mali oranların ortalamaları ve finansal performansları bakımından anlamlı bir farklılık olmadığı yönündedir.

\section{Sonuç}

Türkiye'de her ne kadar 2005 yılından bu yana sermaye piyasası kapsamında bağımsız denetim uygulanıyor olsa da, sermaye piyasası dışındaki bağımsız denetim uygulamaları başlangıcının 2011 yılı olduğu dikkate alındığında, kamuoyunun bağımsız denetim hakkında yeterince bilgi sahibi olmadığı söylenebilir. Denetimde finansal tabloların karşılaştırma kriteri olarak kullanılması gereken TMS/TFRS'lerin uygulanmasında zorluklar bulunmakta, özellikle sermaye piyasası dışındaki işletmelerde finansal tabloları üreten muhasebecilerin bu konuda bilgi ve deneyim eksikliği bulunmaktadır. Bu işletmelerin karlarını artırmak ya da azaltmak amacıyla üstlendikleri riskler, işletme performansı üzerinde olumsuz etki yaratmakta, 
denetim riskini artırmakta ve denetim kalitesini azaltmaktadır. Denetime tabi halka açık ve halka açık olmayan işletmeler arasında finansal süreklilik yapısı itibariyle bir karşılaştırma yapılması amacıyla bu çalışmada, Bursa'da faaliyet gösteren ve denetime tabi olan işletmeler ele alınmıştı. Her iki gruptan araştrrma kapsamına alınan işletmelerin borç ödeme güçleri, finansal yapıları, karlılıkları ve varılıklarının etkin kullanımı hakkında bilgi verebilecek oranlar seçilerek, her bir grup için bu oranların ortalamaları arasında farksızlığı savunan $\mathrm{H}_{0}$ ve farklılığı savunan $\mathrm{H}_{1}$ şeklinde kurulan hipotezleri test etmek için Mann Whitney-U analizi kullanılmıştır. Çalışma kapsamındaki araştırma sonucunda, Bursa'da bağımsız denetime tabi olan halka açık ve halka açık olmayan işletmelerin 2014-2015 yıllarına ait finansal tabloları incelendiğinde likidite oranları ve finansal performansları bakımından anlamlı bir farklılık olmadığı tespit edilmiştir. Buna göre işletmelerin halka açık olması, finansal süreklilik açısından bu işletmeler lehine bir fark yaratmamaktadır. Buna dayanarak, bağımsız denetimde faaliyet raporlarının ve finansal sürekliliğin denetlenmesi 2014 yılı itibariyle uygulanmaya başlandığından, kamuyu aydınlatması gereken, şeffaf ve karşılaştırılabilir finansal tablolar hazırlayan halka açık işletmelerde bu konuda halen bir önlem alınmamış olduğu söylenebilir.

Türkiye'de faaliyet raporlarının bağımsız denetimine ilişkin BDS 700'ün yayımlanma yılı 2014 olduğundan, bu çalışmada incelemeye alınan finansal tablolar 2014-2015 yılı karşılaştırmalı finansal tabloları ile sınırlandırımış ve araştırma kapsamı Bursa'da faaliyette bulunan denetime tabi halka açık ve halka açık olmayan işletmeler ile sınılı tutulmuştur. Ayrıca Bursa'da faaliyette bulunan halka açık işletmelerin tümünün finansal tablolarına ulaşılabildiği halde, halka açık olmayan işletmelerden finansal tablolarına ulaşılabilen işletme sayısının toplam sayıya oranı \%20,5 olarak gerçekleşmiştir. Bu durumun nedeni halka açık olmayan işletmelerin finansal bilgilerini paylaşmaya istekli olmamasından kaynaklanmaktadır. Çalışmamızdaki bu kısıtların, daha sonra yapılacak olan çalışmalar ile aşılması hedeflenerek finansal süreklilik konusunda farklı bölgeler ya da Türkiye geneli için daha detaylı analizler yapılabilir.

\section{Son Notlar}

1. Bu çalışma Uludağ Üniversitesi Bilimsel Araştrma Projeleri tarafindan desteklenen KUAP(i)2015/73 numaralı proje kapsamında hazırlanmıştir.

2. "TMS 1 Finansal Tabloların Sunuluşu" Standardı 31.12.2005 tarihinden sonra başlayan hesap dönemleri için uygulanmak üzere ilk olarak 16.01.2005 tarih ve 25702 sayılı Resmi Gazetede yayımlanmıs, Uluslararası Finansal Raporlama Standartlarında meydana gelen değişikliklere paralellik sağlanması amacıyla 2015 yılına kadar on yedi defa güncellenmiştir.

\section{Kaynaklar}

6102 Sayılı Türk Ticaret Kanunu, 14.02.2011 tarihli 27846 sayılı Resmi Gazete.

Acar, M.(2003). Tarımsal işletmelerde finansal performans analizi. Erciyes Üniversitesi iktisadi ve Idari Bilimler Fakültesi Dergisi, Sayı: 20, 21-37.

Akbulut, R., \& Ömer, F. R. (2015). BIST'te imalat sektöründeki işletmelerin finansal performansları üzerine bir araştrrma. Muhasebe ve Finansman Dergisi, 65, 117-136

Altman, E. I. (1968). Financial ratios, discriminant analysis and the prediction of corporate bankruptcy. The Journal of Finance, 23(4), 589-609.

BDS 570 İşletmenin Sürekliliği Standardı, 23.01.2014 tarihli,28891 sayılı Resmi Gazete'de yayımlanmış 24.03.2017 tarihli ve 30017 sayılı Resmi Gazete'de (Mükerrer) yayımlanan değişiklik Tebliğiyle güncellenmiştir.

BDS 700, Finansal Tablolara iliş̧in Görüş Oluşturma Ve Raporlama, 8.03.2014 tarihli ve 28945 sayılı Resmi Gazete'de yayımlanmış 24.03.2017 tarihli ve 30017 sayılı Resmi Gazete'de (Mükerrer) yayımlanan değişiklik Tebliğiyle güncellenmiştir.

BDS 720 Bağımsı Denetçinin Denetlenmiş Finansal Tabloları içeren Dokümanlardaki Diğer Bilgilere iliş̧kin Sorumlulukları, 14.03. 2014 tarihli 28941 sayılı Resmi Gazete.

Bilgin, M.H. (2011). Bursa'daki En büyük 250 firma araştırması: 2011 yılı sonuçları üzerine değerlendirme. Bursa Ekonomi BTSO Yayını, 74-77. 
Büyüköztürk, Ş. (2013), Sosyal bilimler için veri analizi el kitabı. Ankara: Pegem Akademi, 18. Baskı.

Delen, D., Kuzey, C., \& Uyar, A. (2013). Measuring firm performance using financial ratios: A decision tree approach. Expert Systems with Applications, 40(10), 3970-3983.

Deron, L.C., Chi Lu C., - Fong Tsai, G., \& Shih A., (2016). Financial ratios and corporate governance Indicators in bankruptcy prediction: A comprehensive study. European Journal of Operational Research, 252, 561-572.

Dumanoğlu, S., \& Ergül, N. (2010). IMKB'de işlem gören teknoloji şirketlerinin mali performans ölçümü. Muhasebe ve Finansman Dergisi, 48, 101-111

Hendriksen, E., \& Van Breda, M. F. ( 1992). Accounting theory. Irwin Inc.

Emie, F.Z., \& Hashim, H.A. (2016). Detecting fraudulent financial reporting using financial ratio. Journal of Financial Reporting and Accounting, 14(2), $266-278$.

Gücenme Gençoğlu, Ü., (2014). Finansal tablolar analizi. Bursa: Aktüel.

Gümrük ve Ticaret Bakanlığı, Şirketlerin Yıllık Faaliyet Raporunun Asgari İçeriğinin Belirlenmesi Hakkında Yönetmelik, 28.08.2012 tarih ve 28395 sayılı Resmi Gazete.

Horngren, C. T., Harrison, W. T., \& Oliver, S., (2012). Financial and managerial accounting. Pearson Prentice Hall, New Jersey.

IFRS Foundation (2013). A guide through international financial reporting standards part A, UK.

İçerli, M. Y., \& Akkaya, G. C. (2006). Finansal açıdan başarılı olan işletmelerle başarısız olan işletmeler arasında finansal oranlar yardımıyla farklılıkların tespiti. Atatürk Üniversitesi Iktisadi ve Idari Bilimler Dergisi, 20, 413-421.

Kartal, M., (2014). Bilimsel araştrrmalarda hipotez testleri. Ankara: Nobel.

Lazol, İ., (2011). Bursa'daki en büyük 250 firmanın sektörel açıdan finansal durum analizi. Bursa Ekonomi BTSO Yayını, 49-61.

Ömürbek, V., \& Kınay, Ö. G. B. (2013). Havayolu taşımacılığı sektöründe TOPSIS yöntemiyle finansal performans değerlendirmesi. Süleyman Demirel Üniversitesi Iktisadi ve Idari Bilimler Fakültesi Dergisi, 18(3), 343-363

Pur, D.,- Jacova, H., \& Horak, J. (2015). An evaluation of selected assets and their impact on the declarative characteristic of ratio indicators in financial analyses. Economy and Management, (4), 132-149.

Savsar, A., \& Karaca S.S. (2012). The effect of financial ratios on the firm value: Evidence from Turkey. Journal of Applied Economic Sciences, 1(19), 56-63.

Sermaye Piyasası Kurulu, Seri: X, No: 22 "Sermaye Piyasasında Bağımsız Denetim Standartları Hakkında Tebliğ", 12.06.2006 tarihli ve 26196 sayılı Resmi Gazete.

Selimoğlu, S., \& Orhan, A. (2015). Finansal başarısızlığın oran analizi ve diskriminant analizi kullanılarak ölçümlenmesi: BisT'de işlem gören dokuma, giyim eşyası ve deri işletmeleri üzerine bir araştırma. Muhasebe ve Finansman Dergisi, 17, 21-40.

Sümbüloğlu, K., \& - Sümbüloğlu, V., (2005). Biyoistatistik, Ankara: Hatiboğlu basım ve Yayım.

Taylor, G., \& Tower, G. (2011). Determinants of financial ratio disclosure patterns of Australian listed extractive companies. Australian Accounting Review, 21(3), 302-314.

Tayyar, N., Akcanlı, F., Genç, E., \& Erem, I. (2014). BisT'e kayıtlı bilişim ve teknoloji alanında faaliyet gösteren işletmelerin finansal performanslarının analitik hiyerarşi prosesi (AHP) ve gri ilişkisel analiz (GiA) yöntemiyle değerlendirilmesi. Muhasebe ve Finansman Dergisi, 16, 19-40.

TMS 1- Finansal Tabloların Sunuluşu Standardı, “16/01/2005 tarihli ve 25702 sayılı Resmi Gazete.

Uygurtürk, H., \& Korkmaz, T. (2012). Finansal performansın TOPSIS çok kriterli karar verme yöntemi ile belirlenmesi: Ana metal sanayi işletmeleri üzerine bir uygulama. Eskişehir Osmangazi Üniversitesi iiBF Dergisi, 7(2), 95-115. 
This Page Intentionally Left Blank 